ACTA MYCOLOGICA

Vol. 41 (2): 223-228

2006
Dedicated to Professor Alina Skirgietto

on the occasion of her ninety fifth birthday

\title{
Armillaria ectypa, a vulnerable indicator of mires
}

\author{
ESTERI OHENOJA \\ Botanical Museum, University of Oulu \\ P.O. Box 3000, FI 90014, esteri.ohenoja@oulu.fi
}

Oh e noja E.: Armillaria ectypa, a vulnerable indicator of mires. Acta Mycol. 41 (2): 223 228, 2006.

A boreal montane basidiomycete, Armillaria ectypa, occurs as occasional in northern Finland, mainly in the aapa mire area. According to the IUCN criteria it has been classified as a vulnerable fungus in Finland. Its ecology is in some way connected e.g. to the carices of wet mesotrophic mires.

Key words: Armillaria ectypa, Agaricales, Marasmiaceae, Tricholomataceae, ecology, threat

\section{INTRODUCTION}

The genus Armillaria belongs to the basidiomycete family Marasmiaceae (Tricholomataceae), Agaricales. There occur all four species of the genus Armillaria in Finland (A. borealis, A. cepistipes, A. ectypa, A. ostoyae). A. borealis is common in Finland, rarer in the northernmost Lapland, $A$. cepistipes is occasional, and $A$. ostoy$a e$ is rare occurring in southern and central Finland. A. ectypa has, on the contrary, a northern distribution (O h e noja 1996).

\section{DESCRIPTION OF THE SPECIES}

Armillaria ectypa has (Fig. 1) 5-10 cm high fruit bodies, cap 2-5 cm in diameter, hygrophan, somewhat glossy or fatty, pale ochraceous, brownish when dry, centre covered by faint dark scales or striae, margin later translucently striated. Gills decurrent, rather narrow, whitish first, later ochraceous. Stem slender, 5-10 x 0,5-1,5 $\mathrm{cm}$, lower part often thicker (depending on the consistence of substrate), fibrillose, of the same colour as the cap, base felty. Flesh watery, whitish, taste mild, smell fungous or slightly anisate.

Basidia 4-spored, 32-40 x 6-9 $\mu \mathrm{m}$ in size, sterigmata 2-4 $\mu \mathrm{m}$ long. Spore print white or creamish, spores subglobose or ovoid, 7.0-9.0 x 5.5-6.5 $\mu \mathrm{m}$. Clamps not seen. 


\section{ECOLOGY AND DISTRIBUTION}

Armillaria ectypa has been found in Finland mainly in the northern parts of the country (Fig. 2), its occurrence concentrating to the aapa mire zone. Typical habitats are mesotrophic, thin-turfy, often rocky or stony pine bogs or fens and alluviated shores of ponds (Fig. 3). It often grows on wet substrate, on tufts of decaying carices, as Carex rostrata, $C$. lasiocarpa and $C$. aquatilis. The vascular plants, mosses and fungi found in the closest neighbourhood of A. ectypa are listed in Tab. 1.

The southernmost known localities of Armillaria ectypa are in the southern coast of Finland, but those two habitats at Vantaa (Tab. 2) have not been checked since the species was found in 1959 and 1966. From Janakkala it has been collected last time in the year 1982. This mire is still in good condition and protected, but the occurrence of $A$. ectypa has not been annually monitored. Some habitats in the northern mires are spoiled in some amount because of draining bogs or constructing reservoirs, but very few of them have been studied later. At least one of them is totally flooded into a reservoir. About one half of the localities in Finland are situated in nature reserves.

$357,7535 \mathrm{~S}$

$360,7457 \mathrm{~A}$

377,7171 A

$381,6685 \mathrm{~S}$

381,6766 A

$383,6686 \mathrm{~S}$

$388,7447 \mathrm{~S}$

$389,7440 \mathrm{~S}$

$390,7350 \mathrm{~A}$

$409,7348 \mathrm{~S}$

$410,7450 \mathrm{~S}$

$412,7418 \mathrm{~S}$

$414,7281 \mathrm{~S}$

$416,7071 \mathrm{~S}$

$425,7240 \mathrm{~A}$

$435,7262 \mathrm{~A}$

$452,7235 \mathrm{~S}$

$453,7222 \mathrm{~A}$

493,7353 A

$499,7228 \mathrm{~S}$

$500,7388 \mathrm{~A}$

$503,7734 \mathrm{~S}$

$508,7451 \mathrm{~A}$

$510,7451 \mathrm{G}$

$524,7544 \mathrm{~A}$

$538,7200 \mathrm{~A}$

$539,7265 \mathrm{~S}$

$539,7446 \mathrm{~A}$

$543,7231 \mathrm{~S}$

$569,7349 \mathrm{~A}$

$576,7461 \mathrm{~A}$

$583,7418 \mathrm{~A}$

603,7367 A

$604,7364 \mathrm{~A}$

$607,7239 \mathrm{~A}$

$609,7340 \mathrm{~A}$

715,6949 A
Muonio Rahtusenjärvi

Kolari Sieppijänkkä

Raahe Rytilampi

Vantaa Kaivoksela

Janakkala Suurisuo

Vantaa Sillböle

Kolari Pasmajärvi

Kolari Kaakkuririipilampi

Tornio Sorvasvaara

Tervola Ruuttulampi

Rovaniemi Lohiniva

Rovaniemi Marrasjärvi

Kuivaniemi Ihanalampi

Haapajärvi Kurikkalampi

Haukipudas Syvä Susijärvi

Ii Rytisuo

Haukipudas Kallioselkä

Kiiminki Kourilampi

Ranua Tyyräsenjärvi

Pudasjärvi Koirapuro

Kemijärvi Sammalvaara

Utsjoki Kenesjärvi

Pelkosenniemi Ahma aapa

Pelkosenniemi Korpela

Sodankylä Posoaapa

Puolanka Vantaslahti

Taivalkoski Tutulampi

Savukoski Kätkäaapa

Pudasjärvi Huosiosoja

Posio Riisitunturi

Savukoski Sattoaapa

Salla Aatsinginhauta

Kuusamo Rytilampi

Kuusamo Hiidenlammet

Suomussalmi Takkosenlampi

Kuusamo Vaimojärvi

Ilomantsi Kuikkalampi

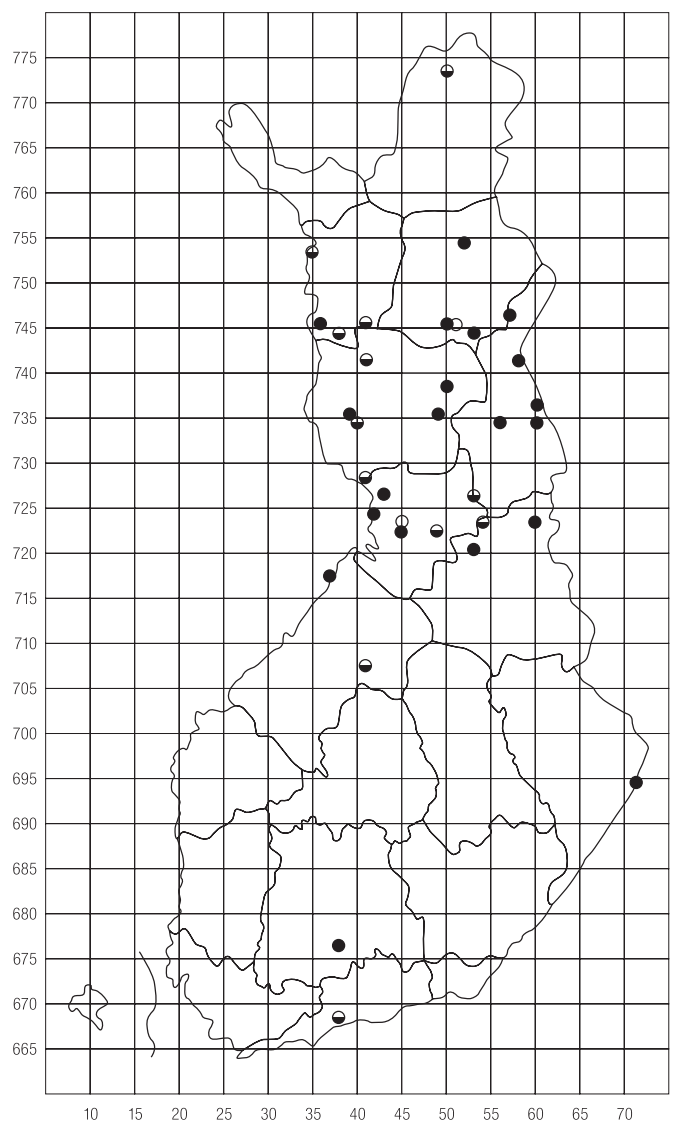

Fig. 2. Distribution of Armillaria ectypa in Finland. (Grid $27^{\circ} \mathrm{E}$ )

- Found after the year 1980 (A) $\odot$ Found before the year 1980 (S)

Extinct $(\mathrm{G})$ 
Table 1

Vascular plants, mosses and fungi found in the closest neighbourhood of Armillaria ectypa in Finland

\begin{tabular}{|ll|}
\hline Vascular plants & Equisetum fluviatile \\
Carex aquatilis & Selaginella selaginoides \\
Carex chordorrhiza & Mosses \\
Carex echinata & Sphagnum angustifolium \\
Carex lasiocarpa & Sphagnum lindbergii \\
Carex limosa & Sphagnum majus \\
Carex magellanica & Sphagnum platyphyllum \\
Carex panicea & Sphagnum recurvatum \\
Carex rostrata & Sphagnum subsecundum \\
Carex rotundata & Aulacomnium palustre \\
Phragmites australis & Cinclidium subrotundum \\
Molinia caerulea & Loeskypnum badium \\
Eriophorum gracile & Paludella squarrosa \\
Eriophorum latifolium & Pseudocalliergon trifarium \\
Trichophrum alpinum & Scorpidium revolvens \\
Trichophorum cespitosum & Scorpidium scorpioides \\
Dactylorhiza incarnata & Straminergon stramineum \\
Salix lapponum & Warnstorfia exannulata \\
Betula nana & Warnstorfia procera \\
Betula pubescens & Warnstorfia sarmentosa \\
Ranunculus hyperboreus & \\
Menyanthes trifoliata & Fungi \\
Drosera anglica & Laccaria proxima \\
Andromeda polifolia & Lactarius pubescens \\
Vaccinium oxycoccus & Lyophyllum palustre \\
Pedicularis palustris &
\end{tabular}

Table 2

The localities of Armillaria ectypa in Finland

Abrreviations: U InL biological provinces; $H$ Herbarium of the University of Helsinki, JOE Her barium of the University of Joensuu, OULU Herbarium of the University of Oulu, TUR A Herbarium of the Abo Akademi .

Uusimaa (U). Vantaa 30.8.1959 (H), 18.9.1966 (H)

Etelä-Häme (EH). Janakkala 16.9.1957 (H), 4.9.1971 (H), 2.9.1982 (H), 7.9.1982 (H)

Pohjois-Karjala (PK). Ilomantsi 27.8.1996 (H, JOE)

Keski-Pohjanmaa (KP). Haapajärvi 22.7.1970 (OULU), Raahe 15.9.1983 (OULU).

Kainuu (Kn). Puolanka 2.8.1989 (OULU), 25.7.1990 (OULU)

Oulun Pohjanmaa (OP). Haukipudas 3.8.1968 (OULU), 17.8.1988 (OULU), Kuivaniemi 29.7.1970 (OULU), Pudasjärvi 24.7.1975 two finds (OULU), 9.8.1977 (OULU), Ii 6.8.1985 (OULU), Kiiminki 1.9.1999 (OULU).

Perä-Pohjanmaa (PeP). Rovaniemi rural commune 23.7.1976 (OULU), 24.7.1976 (OULU), Tervola 29.7.1978 (OULU), Ranua 30.7.1992 (OULU), Kemijärvi 26.7.1993 two finds (OULU), Tornio 20.9.1998 (OULU).

Koillismaa (Ks). Taivalkoski 6.8.1979 (OULU), Kuusamo 25.7.1986 (OULU), 20.8.2005 (OULU), 21.8.2005 (OULU), 24.8.2005 (TUR-A), 1.9.2005 (OULU), Posio 23.8.2005 (OULU), Salla 20.7.1994 (OULU).

Kittilän Lappi (KiL). Muonio 7.8.1970 (Arch. OULU), Kolari 31.7.1970 two finds (OULU), 29.8.1997 (Arch. OULU)

Sompion Lappi (SoL). Pelkosenniemi 3.8.1984 two finds (OULU), 23.7.1995 (OULU), Savukoski 23.7.1995 two finds (OULU), 10.8.2001 (OULU). Inarin Lappi (InL). Utsjoki 14.9.1972 (OULU). 
The 44 samples from Finland are from 30 years between 1959 and 2005, mostly one find per season, but there are 3-5 finds from the years 1970, 1995 and 2005. A special study has not been done and the fungus has been found usually in connection of the flora and vegetation inventories. As for the phenology of the species its finds have been made in Finland in July - September $\left(20^{\text {th }}\right.$ July $-18^{\text {th }}$ September $)$, the main fruiting time being in the southern half of the country somewhat later than in the North.

Armillaria ectypa is, according to the criteria of IUCN, a vulnerable fungus in Finland (Rassi et al. 2001) and a good indicator of the mesotrophic mire habitats.

Armillaria ectypa was found in 12 European countries (D a hlb e rg, Cro n e b org 2003), but it is rare everywhere, also in Finland where it has, however, more localities than elsewhere in Europe. In Sweden the threat class is NT, near threatened, in Denmark EN, endangered. It has never been seen in Norway neither in Estonia nor Iceland. It is considered extinct in Switzerland and Poland, and in MecklenburgVorpommern it had been seen last time in the year 1959 (Kre is el 1992). It is one of the 33 fungus species proposed to the Bern Convention (Dahlberg, Croneborg 2003).

\section{DISCUSSION}

Distribution of Armillaria ectypa seems to be boreal-montane and maybe also continental. The ecology of it is different from the other species of the genus, and very poorly known, thus far. It 's mycelium grows in very wet substrate and can survive in low oxygen conditions. Some species of Armillaria can oxygenate its rhizomorphs in very wet conditions (Ainsw orth 2003), but no rhizomorphs have been detected in $A$. ectypa. There grows in Canada $A$. sinapina except on wood also in wet fens (Thormann et al. 2001), where its mycelium has been isolated from the rhizomes and decomposing leaves of Carex aquatilis, and also from decomposing Salix planifolia leaves. Some species of Armillaria can form a mutualistic relationship with the rhizomes of e.g. orchids. Th orm an n et al. (2001) think that a possible relationship can also exist between $A$. ectypa and Carex aquatilis. If this kind of mycorrhizal connection really exists, it is very likely that also $C$. rostrata and some other carices could be suitable symbionts. There are in the bases of stems in our samples often roots, stems and leaves of carices and salices, but no proper study has been done in the field. Such study is needed, for which the habitats in northern Finland should suit well.

Except for the ecology, the homothallism of the species also is its special characteristic deviating from the other species of the genus. Chillali et al. (1998) suppose that Armillaria ectypa separated, as A. tabescens, too, earlier in the evolution than the other species of the genus.

A question arises if this homothallic mode of reproduction is limiting its ecological capacity so that its impact to changing environment were weaker than that of the heterothallic species? On the contrary the genesis of new mycelia could in theory be easier for these kinds of fungi. 


\section{REFERENCES}

Ainsworth A.M. 2003. Report on the marsh honey fungus, Armillaria ectypa, a UK BAP species. English Nature 540: 123.

Chillali M., Wipf D., Guillaumin J. J., Mohammed C., Botton B. 1998. Delineation of the European Armillaria species based on the sequences of the internal transcribed spacer (ITS) of ribosomal DNA. The New Phytologist 138: 553561.

Croneborg H., Dahlberg A., Halling äck T. 2002. Sällsynta svampari i Sverige. Arter som kan komma att bli rödlistade år 2005. ArtDatabanken, SLU. 72 pp.

Dahlberg A., Croneborg H. 2003. 33 threatened fungi in Europe. Complementary and revised information on candidates for listing in Appendix I of the Bern Convention. $82 \mathrm{pp}$.

Kre is el H. 1992. Rote Liste der gefährdeten Grosspilze Mecklenburg Vorpommerns. Die Umweltmi nisterin des Landes Mecklenburg Vorpommern. $46 \mathrm{pp}$.

Ohe noj a E. 1996. Nevamesisieni, Armillaria ectypa, Suomessa. (Summary: Armillaria ectypa in Fin land.). Sienilehti 48 (3): 8890.

Rassi P., Alanen A., Kanerva T., Mannerkoski I. (eds). 2001. Suomen lajien uhanalaisuus 2000. Suomen ympäristö 495: 1 432. Helsinki.

Thormann M.N., Myrholm C.L., Mallett K.I. 2001. Armillaria sinapina in herbaceous plant material from a peatland in Alberta, Canada. Can. J. Bot. 79 (5): 643647.

\section{Armillaria ectypa, zagrożony gatunek wskaźnikowy torfowisk}

\section{Streszczenie}

Armillaria ectypa, gatunek borealno górski, znany jest z licznych stanowisk w północnej Finlandii. Zajmuje wilgotne siedliska, często spotykany jest w darniach, na obumarłych pe dach turzyc, głównie Carex rostrata i $C$. aquatilis. W pracy zestawione są rośliny naczyniowe, mszaki i grzyby towarzyszące $A$. ectypa, jak również rozmieszczenie stanowisk tego gatunku na terenie Finlandii. 
